Journal of Thermal Engineering, Vol. 7, No. 4, pp. 773-790, May, 2021

Yildiz Technical University Press, Istanbul, Turkey

\title{
PERFORMANCE ANALYSIS OF A MICRO HEAT EXCHANGER IN ELECTRONIC COOLING APPLICATIONS
}

\author{
Mahdi Mokrane ${ }^{1,2^{\star}}$, Mourad Lounis ${ }^{3}$, Mohamed Announ ${ }^{1}$, Maamar Ouali $^{2}$, Med Ali Djebiret ${ }^{2}$, Mahmoud \\ Bourouis $^{4}$
}

\begin{abstract}
To operate under normal conditions and depending on the technology used, the electronic components must be at a temperature below 80 to $85^{\circ} \mathrm{C}$. Several cooling systems were investigated with the aim of improving the heat transfer process in this kind of applications. Single-phase liquid cooling systems, which mainly consist of a hot watercooled micro-heat exchanger, provide an efficient approach to dissipate heat flows. In the present study, numerical and experimental investigations were carried out to study the characteristics of laminar flow and forced convective heat transfer in micro-channels. The inlet temperature of cooling water ranged from 25 to $65^{\circ} \mathrm{C}$, the Reynolds number of water flow varied from 250 to 2000 , and the electronic power supply component was set at 50,80 and $120 \mathrm{~W}$. The results showed that the micro heat exchanger was able to dissipate around 70 to $78 \%$ of the heat released by the electronic component. As regards the numerical results, it was observed that the inlet water temperature of $55^{\circ} \mathrm{C}$ kept a heat source up to $80 \mathrm{~W}$ for a temperature source below the critical value of $80^{\circ} \mathrm{C}$.
\end{abstract}

Keywords: Cooling of Electronic Components, Micro Heat Exchangers, CFD

\section{INTRODUCTION}

In the current context of miniaturization of electronic systems, surface densities and volume densities of heat transfer are becoming an important issue [1]. The development of these systems depends highly on the ability to manage the heat rejection flows, which in turn require a reliable cooling system and efficient technological innovations. To meet these needs, cooling systems such as micro-heat pipes or micro-heat exchangers are being developed. Such technologies allow heat rejection in a localized manner and therefore, are well adapted to electronic components. In order to operate under normal conditions, the electronic components must be at a temperature below a limit, which depends on the specific technology used. This limit varies from 80 to $85^{\circ} \mathrm{C}$ for electronic applications. To enhance simultaneously the heat dissipation and anti-corrosion performance, composite coating was used to preserve the electronic components [2]. For instance, the use of alkali silicate mixed with nanoparticles was demonstrated to increase thermal conductivity [3-4].

Single-phase liquid cooling systems, which mainly consist of a water-cooled micro-heat exchanger, are well understood and established in heat transfer applications and this has been consistently emphasized in the research community [5].

The use of microchannels for cooling is not new since Tuckerman and Pease proposed introducing it in 1981 [6]. They showed that the size of heat exchangers could be reduced considerably and still achieve the same level of performance or even much higher than that of conventional systems. In 1984 Goldberg [7] investigated the hydrodynamic and thermal performance of an air-cooled copper micro-channel exchanger in forced convection and laminar flow. He studied channels of size $\mathrm{W}_{\mathrm{f}}=\mathrm{W}_{\mathrm{c}}=127,254$ and $635 \mu \mathrm{m}$ with $\mathrm{H}_{\mathrm{c}}=1.27 \mathrm{~cm}$ and $\mathrm{Ly}=0.635 \mathrm{~cm}$. The minimum resistance was obtained with $127 \mu \mathrm{m}$ wide channels. The latter was of the order of $0.88 \mathrm{~cm}^{2} .{ }^{\circ} \mathrm{C} . \mathrm{W}^{-1}$, which is 10 times greater than that obtained by Tuckerman and Pease [6]. In 1985 Mahalingam [8] carried out experiments on silicon microchannels cooled in air and water. The channels had a width of $200 \mu \mathrm{m}$ and a height of $1700 \mu \mathrm{m}$ with a fin thickness equal to $100 \mu \mathrm{m}$. The air-cooling produced a resistance of $10.12\left(\mathrm{~cm}^{2} .{ }^{\circ} \mathrm{C} . \mathrm{W}^{-1}\right)$ and that of water, a

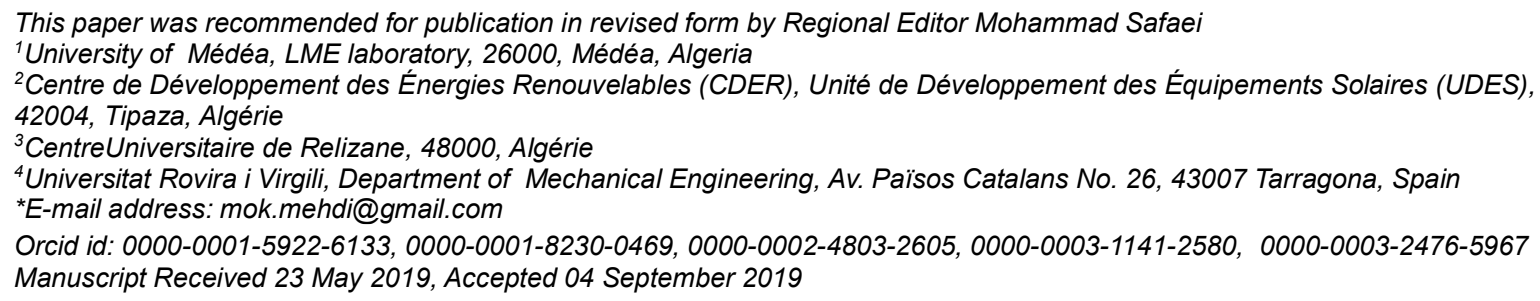


resistance of $0.29\left(\mathrm{~cm}^{2} .{ }^{\circ} \mathrm{C} . \mathrm{W}^{-1}\right)$ which was almost 3.5 times greater than that obtained by Tuckerman and Pease [6] with much larger dimensions.

The different channel heat exchangers used for cooling are classified by order of magnitude of their hydraulic diameter $D_{h}$. The classification given in Table 1 is widely accepted by the majority of institutions concerned with these microstructures, although limits based on very concise scientific or experimental criteria do not yet exist. According to the authors, the classification of micro-channels, mini-channels and macro-channels differ according to the hydraulic diameter. Mehendafe et al. [9] classified the exchangers as follows:

Table 1. Classification of heat exchangers according to Mehendafe et al. [9]

\begin{tabular}{|l|l|}
\hline Micro heatexchanger & $1 \mu \mathrm{m} \leq \mathrm{D}_{\mathrm{h}} \leq 100 \mu \mathrm{m}$ \\
\hline Macro heatexchangers & $100 \mu \mathrm{m} \leq \mathrm{D}_{\mathrm{h}} \leq 1 \mu \mathrm{m}$ \\
\hline Compact heatexchangers & $1 \mathrm{~mm} \leq \mathrm{D}_{\mathrm{h}} \leq 6 \mathrm{~mm}$ \\
\hline Conventionalheatexchangers & $\mathrm{D}_{\mathrm{h}} \geq 6 \mathrm{~mm}$ \\
\hline
\end{tabular}

Table 2. Classification of heat exchangers according to Kandlikar and Grande [10]

\begin{tabular}{|l|l|}
\hline Micro heatexchanger & $10 \mu \mathrm{m} \leq \mathrm{D}_{\mathrm{h}} \leq 200 \mu \mathrm{m}$ \\
\hline Macro heatexchangers & $200 \mu \mathrm{m} \leq \mathrm{D}_{\mathrm{h}} \leq 3 \mathrm{~mm}$ \\
\hline Conventionalheatexchangers & $\mathrm{D}_{\mathrm{h}} \geq 3 \mathrm{~mm}$ \\
\hline
\end{tabular}

Finally, Cavallini et al. indicated that micro-channels correspond to a hydraulic diameter between $0.5 \mathrm{~mm}$ and $3 \mathrm{~mm}[11]$.

Numerous experimental and numerical investigations focused on heat transfer enhancement and fluid flow in microchannels are available in the open literature [12-14]. Peng and Peterson [15] reported that the transition between the laminar and turbulent regimes occurs at Reynolds numbers ranging from 300 to 1000, whereas it is usually around 2300 for conventional cylindrical geometry. Gao at al. [16], on the other hand, reported a regime change at a Reynolds number of 2300 and an improvement in heat exchange with the decrease in the size of the channels. Philips [17] concluded that the fins play a role of pumping power and improve the exchange.

$\mathrm{Qu}$ and Mudawar [18] were also interested in liquid flows through micro-tubes. They digitally analyzed threedimensional flow and thermal transfer performance in a rectangular micro-exchanger formed by one and two layers of silicon and using water as the operating fluid. The micro-channels used, have a width of $57 \mu \mathrm{m}$ and a height of $180 \mu \mathrm{m}$ and were separated by a wall of $43 \mu \mathrm{m}$ in thickness. As regards the micro-exchangers investigated they reported that the temperature increase in the direction of flow at the fluid-solid interface could be assumed linear.

The hot water used for cooling and circulating through microchannels is a preferred solution in computer centers, as in the case of the Super MUC, a supercomputer built by IBM, hosted in a center at Leibniz and put into operation, in 2012 [19]. Another interesting case is the 3 petaflop machine, which is one of the most powerful supercomputers in the world. Its cooling system uses water at about $45^{\circ} \mathrm{C}$ as a cooling medium [19].

Zimmermann et al. [20] presented an experimental study on the cooling of an electronic chip using hot water. The authors proposed the circulation of water at high inlet temperatures with low flow rates in a micro-channel heat sink, in order to significantly reduce or eliminate dependency on the vapor compression cooling system. The use of hot water may seem strange, but it consumes less energy than other cooling methods, because the hot water leaving the system requires less cooling before being re-used.

Several researchers investigated different geometric configurations of microchannel heat sinks such as rectangular [21-23], trapezoidal [24-25], triangular [26] and circular [27-29]. However, a small number of experimental studies have shown that other innovative forms, fan-shaped cavities [30], corrugated [31, 32], tortuous [33, 34] and serpentine [35] channels could provide interesting performance benefits.

The present paper focuses on the efficiency of the use of hot water to cool electronic heating elements by using different powers in order to reduce electric consumption of cooling units in areas with hot climates. For this reason, a thin heat exchanger was designed, built and tested experimentally in cooling mode using distilled water. The results 
obtained using numerical simulations were compared with the results obtained from the experiment. A performance comparison was carried out between the hot water-cooling system proposed in this work and the water-cooling system at a conventional temperature. In Figure.1, the schematic overview of the whole paper is presented.

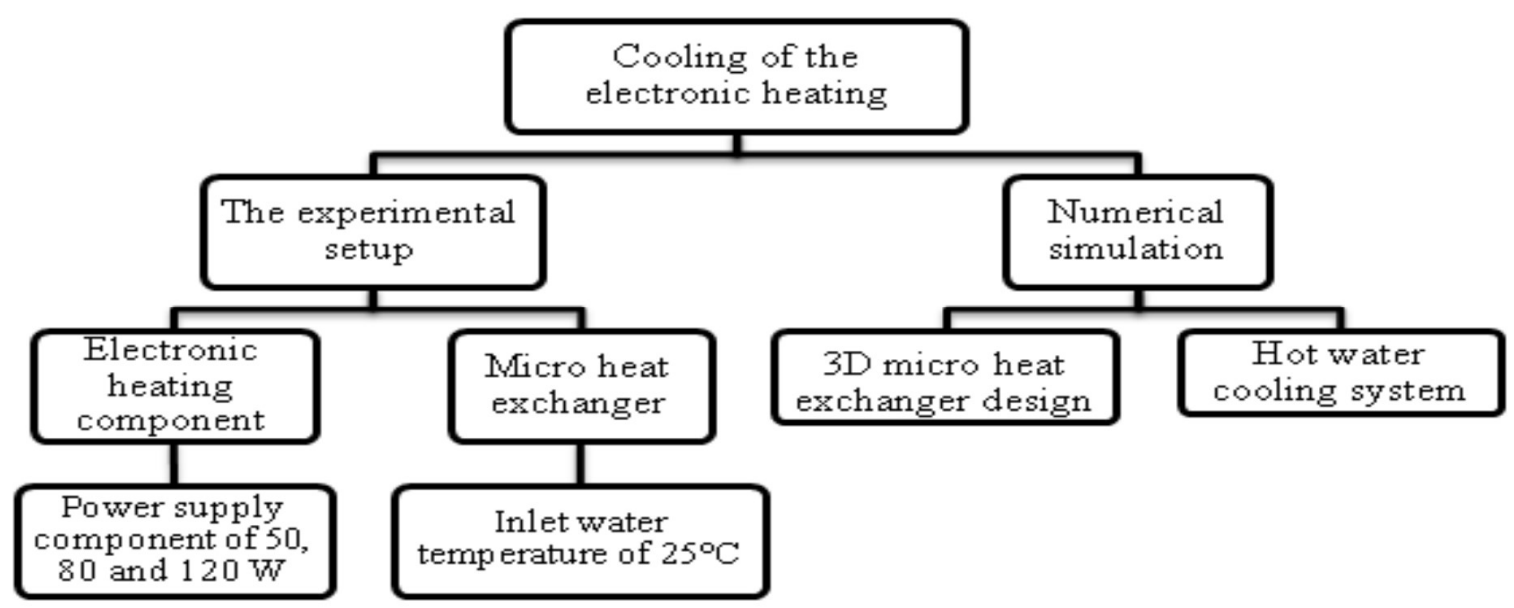

Figure 1. Schematic overview of the present paper.

\section{EXPERIMENTAL SETUP AND MEASUREMENT PROCEDURE}

The experimental setup and the protocol followed to carry out the experiments are described in this paragraph. Figure 2 (a) shows the test section, which consists of a ceramic heating component of $40 \mathrm{~mm}$ in length, $28 \mathrm{~mm}$ in width and a thickness of $5 \mathrm{~mm}$. It is placed on polyurethane insulation and a metal rail in the middle of a 180x130x100 mm parallelepiped box. The heat generation was obtained by the Joule effect, which consists in passing an electric current through the heating component. After measuring the electric current (I) and the voltage (U) across the heating component, the heat generated $(\mathrm{P})$ was calculated as follows in Eq. 1.

$$
P=I x U
$$
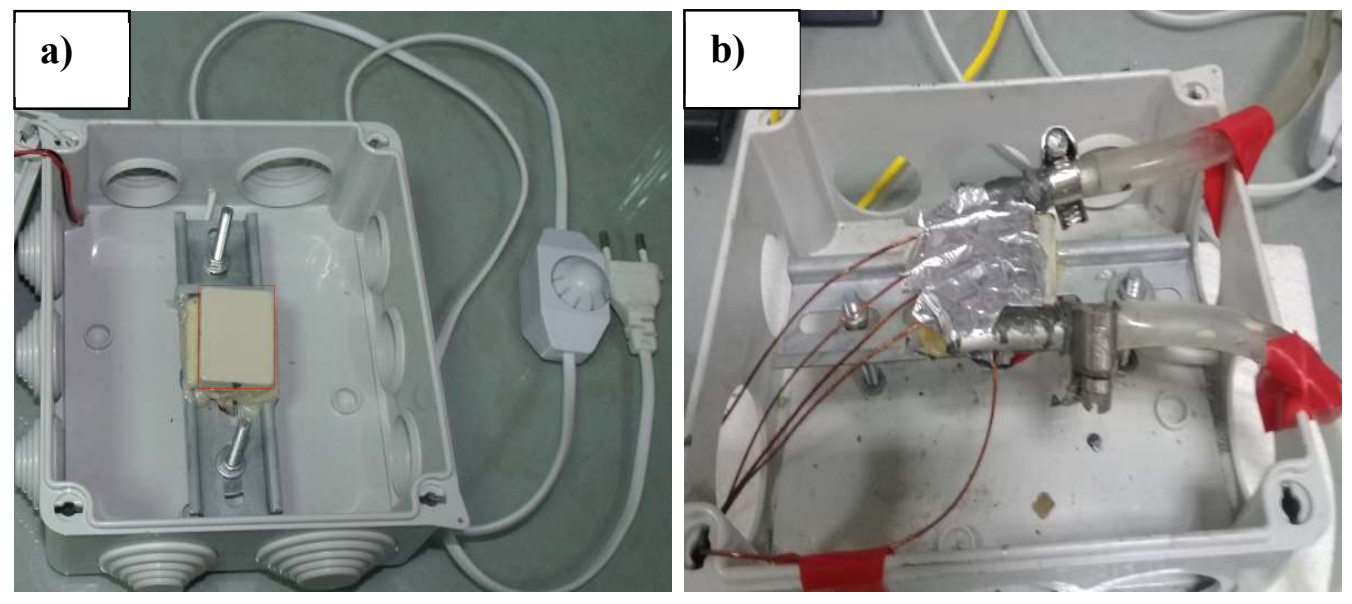

Figure 2. Test section of the experimental setup: a) Heating component, b) Micro heat exchanger.

The experiments were carried out using voltages of 90,150 and $220 \mathrm{~V}$, which correspond to power supplies of 50,80 and $120 \mathrm{~W}$, respectively. This made it possible to generate maximum temperatures of 100,130 and $160^{\circ} \mathrm{C}$, 
respectively. It is worthy of note that the temperature was uniform on the upper surface of the heat source. Figure 2 (b) shows the location of the micro heat exchanger on the heat source.

Figure 3 shows the experimental setup that includes the test section and the other auxiliary components. These consist of a water tank to supply the test section with distilled water at an inlet temperature $\left(\mathrm{T}_{\text {in }}\right)$ of approximately $25^{\circ} \mathrm{C}$, a variable speed prostate pump used for the circulation of water through the micro heat exchanger and a data acquisition system connected to a computer that allows for the visualization and recording of all the parameters measured.

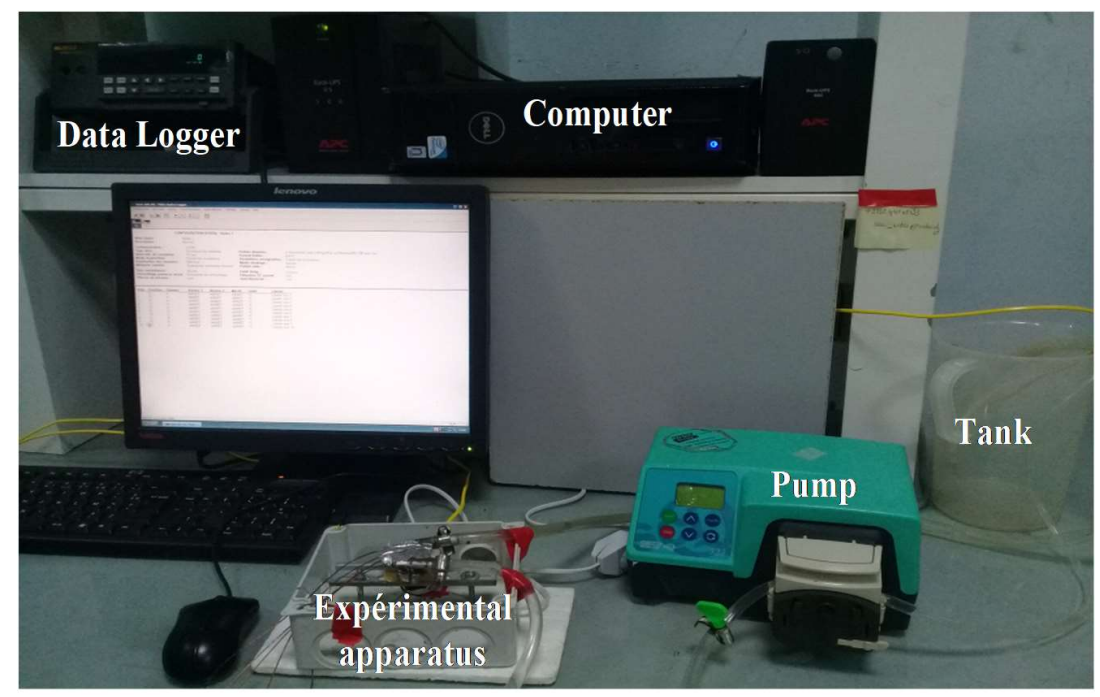

Figure 3. Experimental setup including the test section and auxiliary components.

The micro heat exchanger tested and illustrated in figure 4, consists of 17 aluminum micro-channels of a rectangular section of $1 \mathrm{~mm}$ high and $0.7 \mathrm{~mm}$ wide and a channel length equal to $40 \mathrm{~mm}$. Two circular manifolds of $5 \mathrm{~mm}$ hydraulic diameter, one at the inlet and the other at the outlet, are used to distribute the circulating fluid in all the micro channels.
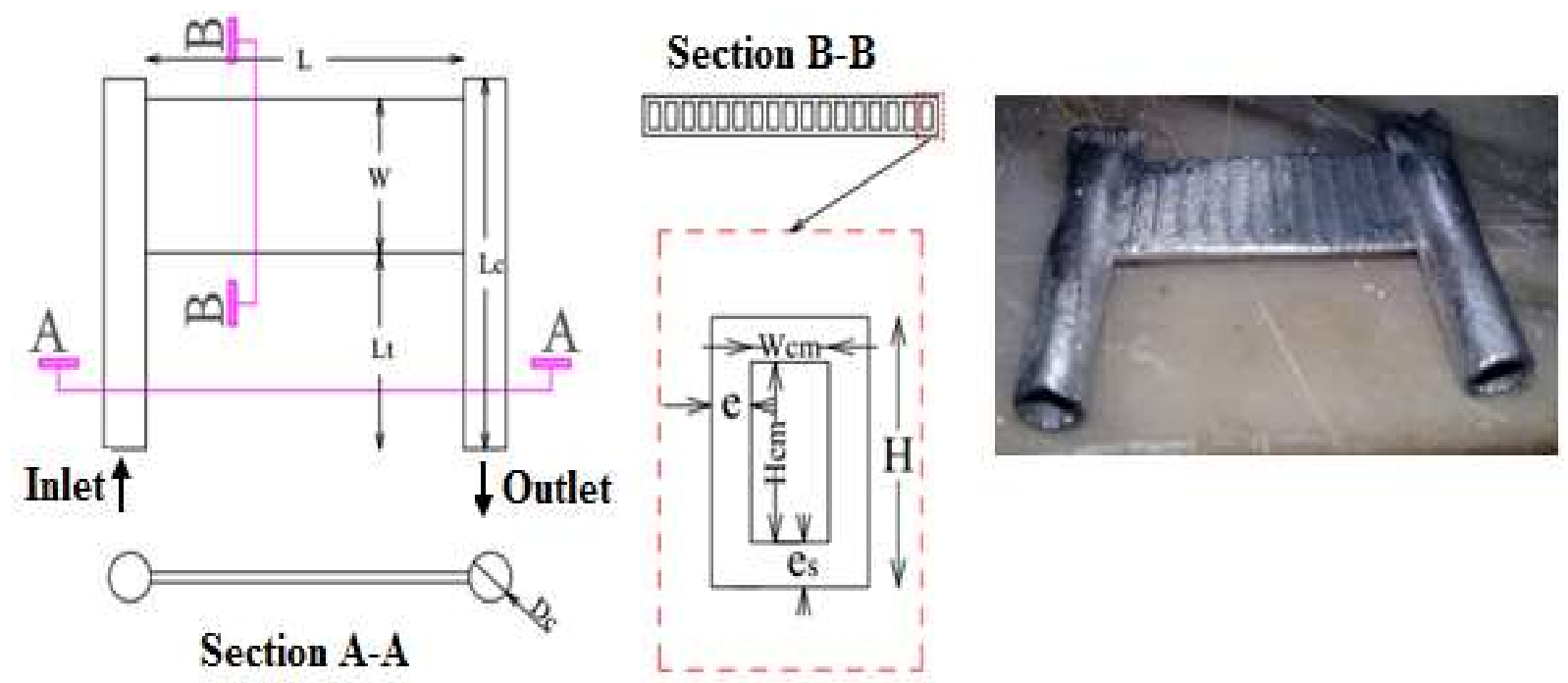

Figure 4. Schematic representation of the micro heat exchanger design.

The geometric dimensions of the micro heat exchanger shown in Figure 4 are summarized in Table 3. 
Table 3. Geometric dimensions of the micro heat exchanger.

\begin{tabular}{|l|c|}
\hline Geometric parameter & Dimension (mm) \\
\hline Plate length $(\mathrm{L})$ & 40 \\
\hline Plate width $(\mathrm{W})$ & 16 \\
\hline Plate height $(\mathrm{H})$ & 1.63 \\
\hline Channel width $\left(\mathrm{W}_{\mathrm{mc}}\right)$ & 0.7 \\
\hline Channel height $\left(\mathrm{H}_{\mathrm{mc}}\right)$ & 1 \\
\hline Half thickness of the solid $\left(\mathrm{e}_{\mathrm{s}}\right)$ & 0.35 \\
\hline Thickness of fins $(\mathrm{e})$ & 0.25 \\
\hline Collector tube length $\left(\mathrm{L}_{\mathrm{c}}\right)$ & 40 \\
\hline Collector tube diameter $\left(\mathrm{D}_{\mathrm{c}}\right)$ & 5 \\
\hline Number of channels $(\mathrm{N})$ & 17 \\
\hline
\end{tabular}

Temperature measurement was carried out using K-type thermocouples installed in eight locations of the experimental setup. Three thermocouples were placed, one in the ambient air, one in the water tank and one in the centre of the outer surface of the heat source. The other five thermocouples were placed along the length of the microchannel each at a spacing of $8 \mathrm{~mm}$. Temperature sensors were monitored by means of a data logger connected to a computer via a graphical communication interface and recorded at time intervals of 10 seconds.

Figure 5 shows the distribution of these thermocouples in the experimental setup. The error range of thermocouple measurement was $\pm 0.1{ }^{\circ} \mathrm{C}$. The experiment was started by setting the voltage regulator at $90 \mathrm{~V}$ and the water flow rate at $100 \mathrm{ml} / \mathrm{min}$, and then stopped after 30 minutes. The experiment was then repeated for water flow rates of 250 and $400 \mathrm{ml} / \mathrm{min}$ at the same voltage. Afterwards, the same experimental procedure was carried out for voltages of $150,220 \mathrm{~V}$, and the same water flow rates, i.e., 100,250 and $400 \mathrm{ml} / \mathrm{min}$. It is worthy of note that before starting a new experiment the heat source was cooled for few minutes.

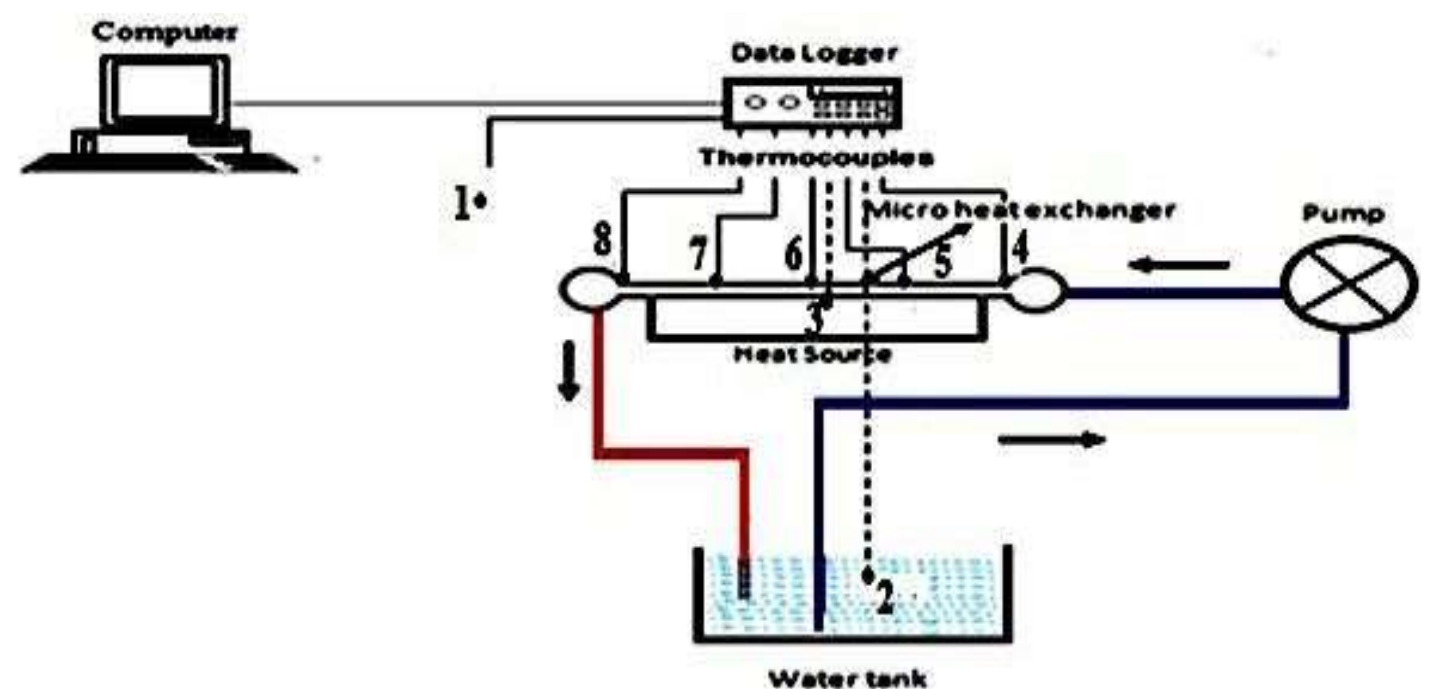

Figure 5. Schematic diagram of the experimental apparatus showing the thermocouple locations.

\section{NUMERICAL ANALYSIS}

The physical model of the numerical simulation developed to investigate the mono-phasic flow inside the micro-channels is presented in this paragraph. The model equations, the boundary conditions and the generation of the mesh required for the numerical simulation are described. The numerical calculation method, the discretization scheme and the calculation algorithm are also presented. 
The layout of the micro heat exchanger tested in the present work is shown in Figure 6. An elementary volume was considered in the calculation model and heat transfer within the micro-channel was simulated using the CFD (computational fluid dynamics) tool ANSYS/FLUENT 14.0.

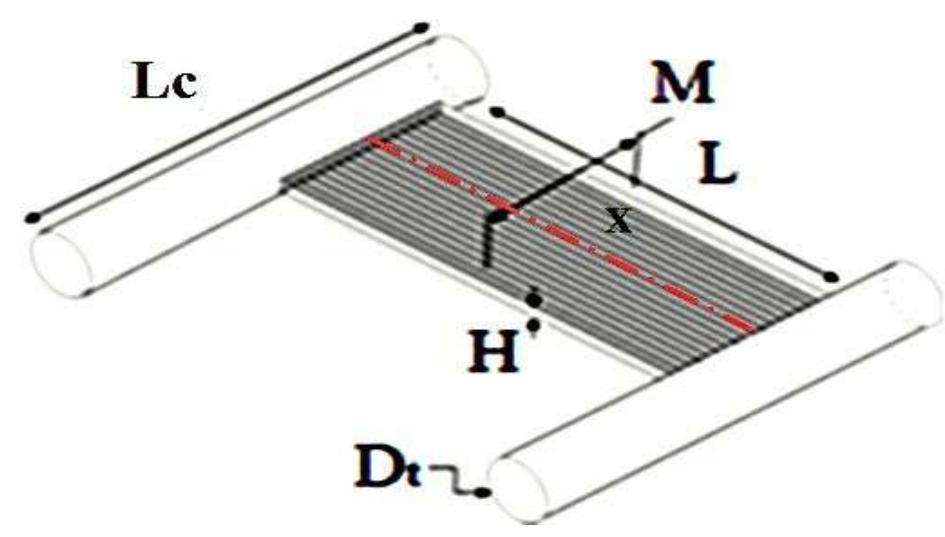

Figure 6. Schematic diagram and calculation volume of the micro heat exchanger.

\section{Mathematical Modeling and Boundary Conditions}

A three-dimensional fluid-solid model was used to predict the cooling performance of the micro heat exchanger investigated. The model takes into account the following assumptions:

- The cooling fluid used is water

- The flow is incompressible, laminar and steady state

- The properties of solids and fluids are constant

- The gravitational force in the momentum equation and the viscous dissipation in the energy equation are neglected

- $\quad$ The heat losses between the radiator and the ambient air are neglected.

\section{Governing Equations}

Based on the above assumptions, the fluid and energy transport equations can be expressed as follows:

Continuity equation for the cooling fluid:

$$
\frac{\partial \rho}{\partial \mathrm{t}}+\nabla(\rho \vec{V})=0
$$

Momentum equation for the cooling fluid:

$$
\rho(\vec{v} \times \nabla \vec{v})=-\nabla P+\mu \nabla^{2} \vec{v}
$$

Energy equation for the cooling fluid:

$$
\rho_{f} C_{p f} \vec{V} \times \nabla T=k_{f} \nabla^{2} T
$$

The energy equation for solid regions can be written as:

$$
k_{S} \nabla^{2} T=0
$$


Reynolds Number:

$$
R e=\frac{\rho \times V \times D_{h}}{\mu}
$$

Hydraulic diameter:

$$
\mathrm{D}_{\mathrm{h}}=\frac{2 \times\left(\mathrm{H}_{\mathrm{mc}} \times \mathrm{W}_{\mathrm{mc}}\right)}{\left(\mathrm{H}_{\mathrm{mc}}+\mathrm{W}_{\mathrm{mc}}\right)}
$$

The thermal resistance is defined by the ratio of the heating element temperature difference and the water inlet temperature to the supplied heating element power, given by:

$$
\mathrm{R}_{\mathrm{th}}=\frac{\mathrm{T}_{\mathrm{s} \text { max }}-\mathrm{T}_{\text {int }}}{\mathrm{Q}}
$$

\section{Boundary conditions}

Numerical simulations were performed varying the water temperature $\left(T_{\text {in }}\right)$ in the entrance collector between 25 and $65^{\circ} \mathrm{C}$ and the Reynolds number from 250 to 2000 . The pressure in the outlet collector was set at the atmospheric pressure. The power of the heat source applied on the lower wall was varied between 50 and $120 \mathrm{~W}$, and corresponds to heat flux ranging from $45 \times 10^{3}$ to $120 \times 10^{3} \mathrm{~W} / \mathrm{m}^{2}$. Walls separating liquid and solid areas were considered as interfaces, while the walls of the entrance and exit of the micro-channels were considered as inner walls. The rest of the walls were defined as adiabatic walls.

To improve the accuracy of the calculations, several numerical tests were performed on different numbers of mesh elements $988469,1088831,1351483$ and 1511798, in order to guarantee the independence of the mesh. For this, the temperature profiles along the micro-channel according to the position $\mathrm{X}$ as shown in Figure 6, was selected as the observation value. Figure 7 shows the mesh refinement test carried out at a Reynolds number of 500, a heat power source of $120 \mathrm{~W}$ and an inlet temperature of $25^{\circ} \mathrm{C}$ for the cooling water. It is observed that mesh with a number of elements equal to 988469 provided a balance between accuracy of results and computational time.

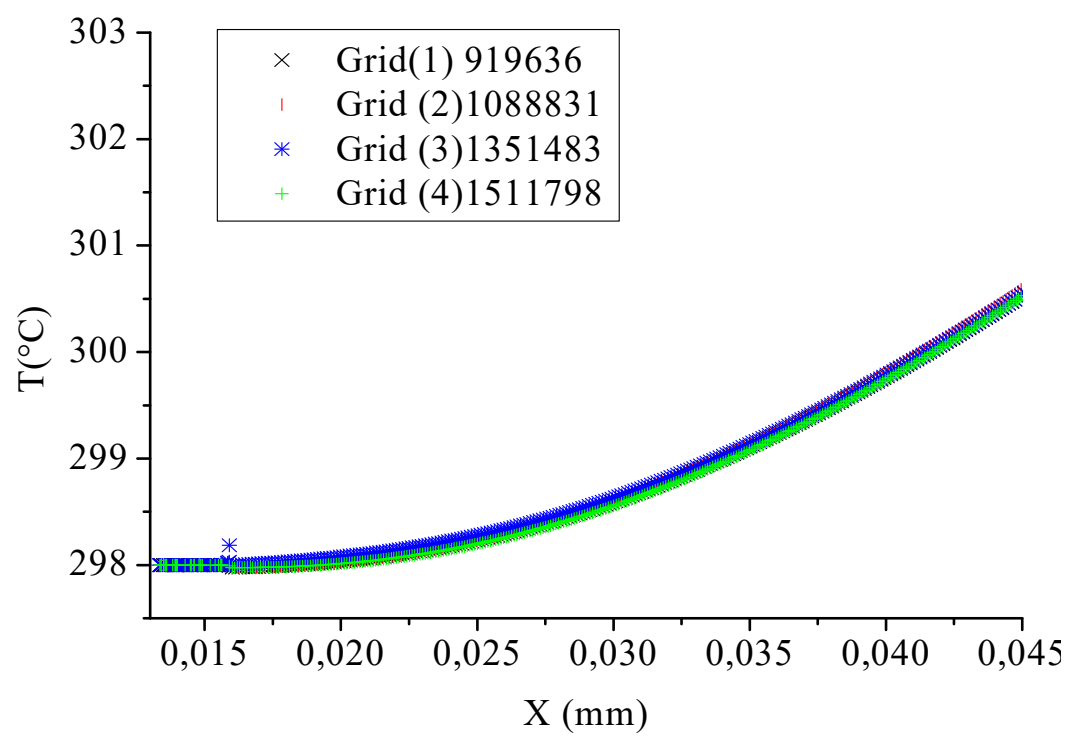

Figure 7. Influence of grid number of temperature change along the centerline of the microchannel. 


\section{Numerical procedure}

The numerical calculation was performed using the CFD ANSYS/FLUENT 14.0. This software allows fluid flows to be predicted by solving balance equations based on the finite volume method. Patankar [36] reported the details of this method. The momentum and energy equations were solved using a second-order upwind scheme and the coupling of pressure fields and speed were controlled by the use of the SIMPLE algorithm. Convergence of the iterative process was considered to have been achieved, when the residuals of the continuity and momentum equations were less than $10^{-4}$ and those of the energy equations were less than $10^{-7}$.

\section{RESULTS AND DISCUSSION}

The results of the experimental and numerical studies carried out in the present work allowed for analysis of the distribution of the temperature fields in the heating component and the flow velocity in the micro heat exchanger.

\section{Experimental Study}

Figure 8 shows the experimental temperature profiles on the upper face of the heating component in two cases. The first case consisted in measuring the temperature of the heat source without cooling at three power supply values, namely 50, 80 and $120 \mathrm{~W}$. In this case the temperature varied with time. When the power supply was set at $50 \mathrm{~W}$, the temperature reached $80^{\circ} \mathrm{C}$ after $600 \mathrm{~s}$ and $100^{\circ} \mathrm{C}$ after $1800 \mathrm{~s}$. At $80 \mathrm{~W}$, the temperature was $80^{\circ} \mathrm{C}$ at $\mathrm{t}=400 \mathrm{~s}$ and around $130^{\circ} \mathrm{C}$ at $\mathrm{t}=1800 \mathrm{~s}$. As regards the $120 \mathrm{~W}$ power supply, the temperature reached about $80^{\circ} \mathrm{C}$ after $200 \mathrm{~s}$ and $160^{\circ} \mathrm{C}$ after $1800 \mathrm{~s}$. Indeed, the speed of the temperature variation of the heating component at $80^{\circ} \mathrm{C}$ with respect to the ambient temperature of $25^{\circ} \mathrm{C}$ during this time interval was:

Power of 50 Wand $t=[0 ; 600 \mathrm{~s}]$

$$
\left.\frac{\Delta T}{\Delta t}\right|_{[0 ; 600 s]}=0.092^{\circ} \mathrm{C} / \mathrm{s}
$$

Power of $80 \mathrm{~W}$ and $\mathrm{t}=[0 ; 400 \mathrm{~s}]$

$$
\left.\frac{\Delta T}{\Delta t}\right|_{[0 ; 400 s]}=0.14^{\circ} \mathrm{C} / \mathrm{s}
$$

Power of $120 \mathrm{~W}$ and $\mathrm{t}=[0 ; 200 \mathrm{~s}]$

$$
\left.\frac{\Delta T}{\Delta t}\right|_{[0 ; 400 s]}=0.275^{\circ} \mathrm{C} / \mathrm{s}
$$

In the second case, the heating component was cooled by means of a micro heat exchanger in which distilled water circulated at an approximate inlet temperature of $25^{\circ} \mathrm{C}$ and three different values of water flow rate, i.e. 100,250 and $400 \mathrm{ml} / \mathrm{min}$ each of which correspond to the Reynolds numbers of 500, 1000 and 2000, respectively.

At a power supply of $50 \mathrm{~W}$, the temperature profiles showed that the temperature of the heating component decreased to $31^{\circ} \mathrm{C}$ when using flow rates of 250 and $400 \mathrm{ml} / \mathrm{min}$ and to $34^{\circ} \mathrm{C}$ at a flow rate of $100 \mathrm{ml} / \mathrm{min}$. However, at $80 \mathrm{~W}$ the temperature of the heating component was maintained at around $34^{\circ} \mathrm{C}$ for the three values of the water flow rate.

When the power was supplied at $120 \mathrm{~W}$, the temperature of the heating component stayed at $38^{\circ} \mathrm{C}$ for the water flow rate of $100 \mathrm{ml} / \mathrm{min}$ and it did not exceed $36^{\circ} \mathrm{C}$ for the flow rates of 250 and $400 \mathrm{ml} / \mathrm{min}$. It is worth note that the micro heat exchanger was able to dissipate around 70 to $78 \%$ of the heat released by the electronic heating component. The thermal resistance of the micro heat exchanger as a function of the heating power is plotted in Figure 9. 

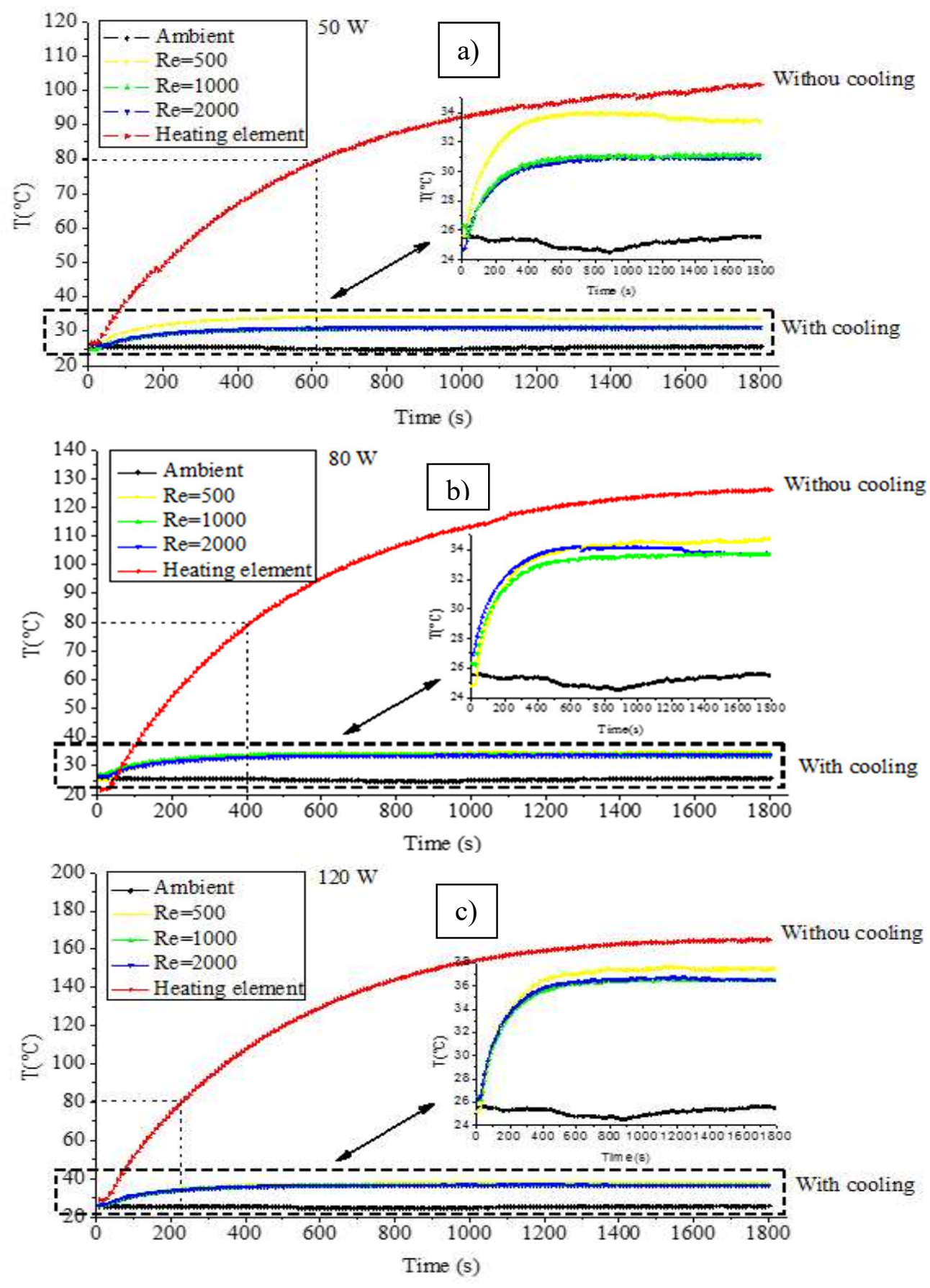

Figure 8. Temperature profile versus time at power supplies of a)50W, b) $80 \mathrm{~W}$ and c) $120 \mathrm{~W}$.

The plotted resistance values were calculated at flow rate of $100,250,400 \mathrm{ml} / \mathrm{mn}$ and a system inlet temperature of $25^{\circ} \mathrm{C}$

It is clear that convective heat transfer is improved by increasing flow rate, which in turn reduces the overall thermal resistance of the heat sink. At a flow rate of $100 \mathrm{ml} / \mathrm{min}$ and thermal loads of 50,80 and $10 \mathrm{~W}$, the thermal resistance of the heat sink was maximum at $0.18,0.12$ and $0.11^{\circ} \mathrm{C} / \mathrm{W}$, respectively. The thermal resistance was further 
decreased by increasing the flow rate. At a flow rate of $400 \mathrm{ml} / \mathrm{min}$, the thermal resistance ranged from 0.09 to $0.1^{\circ} \mathrm{C} / \mathrm{W}$ for all heat loads.

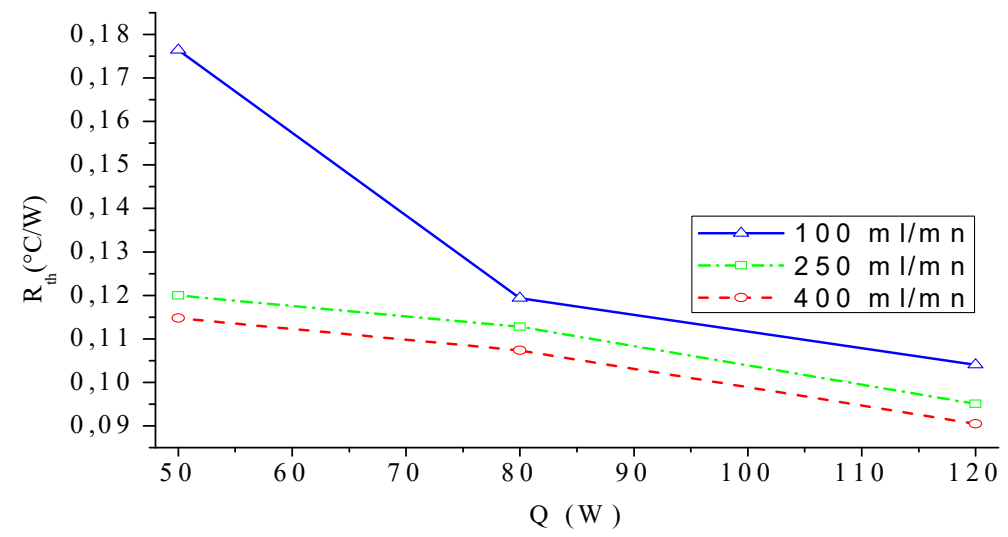

Figure 9. Thermal resistance of the micro heat exchanger as a function of heat load.

\section{CFD Numerical Simulation}

\section{Validation of the calculation code}

The CFD simulation code used was validated by comparing the experimental data with the numerical results obtained at the same working conditions. As a function of the position, the temperature profiles in the micro-channels were compared with those registered by thermocouples 4, 5, 6, 7 and 8 in the experimental work. For this purpose, a position in the micro-channel length was selected at $\mathrm{X}$ as shown in Figure 5.
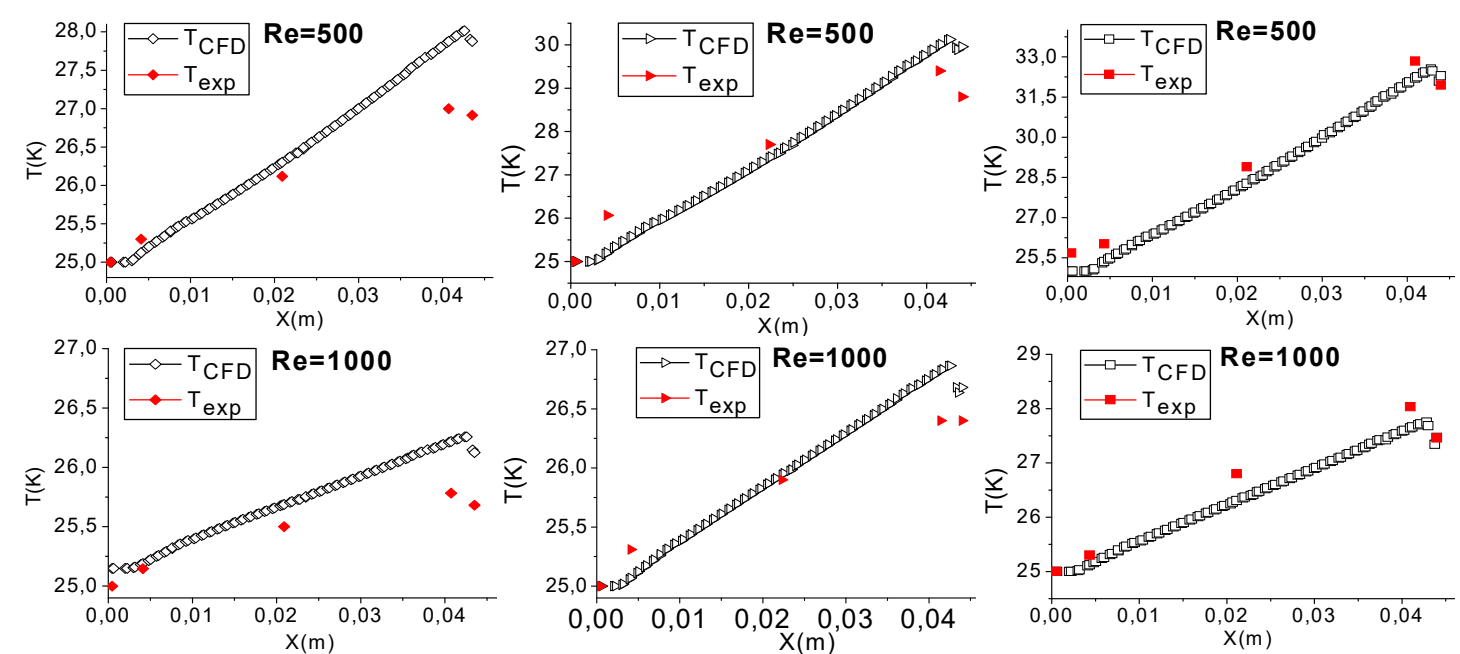

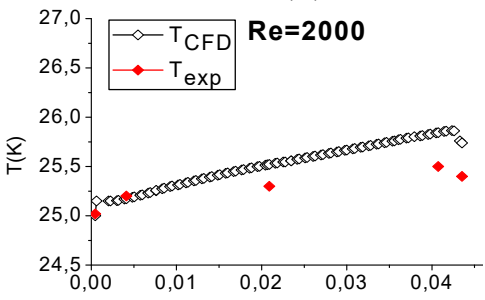

a)

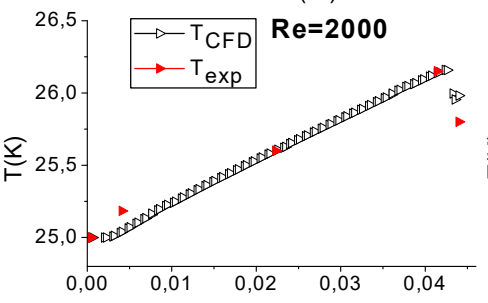

b)

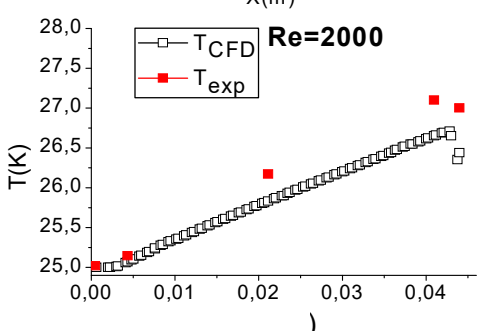

c)

Figure 10. Comparison of experimental data with theoretical results for power supply values of: a) $50 \mathrm{~W}$, b) $80 \mathrm{~W}$, c) $120 \mathrm{~W}$. 
The results illustrated in Figure 10 show that the theoretical profiles are well in agreement with the experimental data. The maximum deviation between the experimental and theoretical values of the temperature was about $3.5 \%$, $3.9 \%$ and $2.1 \%$ for power supply values of 50,80 and $120 \mathrm{~W}$, respectively.

\section{Parametric analysis}

In this section, the numerical results obtained are presented for cooling a heating component with a micro-heat exchanger. The numerical study consists in analyzing the effect of both the inlet temperature and the flow velocity in the micro-channels on the cooling of the heating components. The temperature profiles along the micro-channel according to the position $\mathrm{X}$, where the flow reached a fully developed regime, are shown in Figures 10 to 14 at an inlet water temperature ranging from $25^{\circ}$ to $65^{\circ} \mathrm{C}$ at $10^{\circ} \mathrm{C}$ intervals. As previously mentioned, the target of the cooling system was to maintain the maximum temperature reached by the heating component below $80^{\circ}$, which is the limit permitted. For the safe operation of electronic heating components, the safety temperature $\left(\mathrm{T}_{\mathrm{cs}}\right)$ was set at $70^{\circ} \mathrm{C}$ and was required to dissipate thermal loads ranging from 50 to $120 \mathrm{~W}$. As regards the cooling of solar cells, the maximum temperature was set at $50^{\circ} \mathrm{C}$.

Figure 11 shows that, at an inlet water temperature of $25^{\circ} \mathrm{C}$ and a power supply of $120 \mathrm{~W}$, the temperature difference between the heating component and the critical value of $80^{\circ} \mathrm{C}$ was about $25^{\circ} \mathrm{C}$ for the Reynolds number of 250 and reached $35^{\circ} \mathrm{C}$ for higher values of the Reynolds number. The heating component was cooled at lower temperatures for the other power supply values, namely 50 and $80 \mathrm{~W}$. It was also noted that the temperature of solar cells could be maintained below $50^{\circ} \mathrm{C}$ with an inlet water temperature of $25^{\circ} \mathrm{C}$.

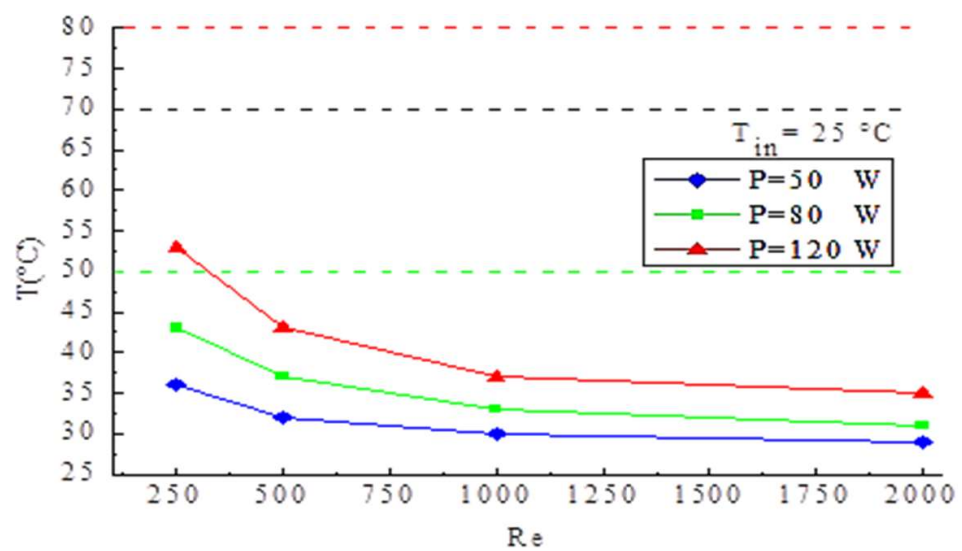

Figure 11. Temperature profiles of the heating component versus Reynolds number at an inlet water temperature of $25^{\circ} \mathrm{C}$ and power supplies of 50,80 and $120 \mathrm{~W}$.

Figure 12 shows that, at an inlet water temperature of $35^{\circ} \mathrm{C}$ and $120 \mathrm{~W}$ of power the difference between the electronic heating component and the critical temperature value of $80^{\circ} \mathrm{C}$ was almost $18^{\circ} \mathrm{C}$ for a Reynolds number of $250,27^{\circ} \mathrm{C}$ for $\mathrm{Re}=500$ and between 30 and $35^{\circ} \mathrm{C}$ for higher values of the Reynolds number. In the case of $80 \mathrm{~W}$, the temperature difference was $27^{\circ} \mathrm{C}$ for a Reynolds number of 250 and between 33 and $39^{\circ} \mathrm{C}$ for the rest of the Reynolds numbers. When the power was set at $50 \mathrm{~W}$, cooling of the electronic heating component was satisfactory for the whole range of Reynolds numbers. As regards the solar cells, cooling fulfilled the target at a power supply of $50 \mathrm{~W}$ over the whole range of Reynolds numbers, while for the power supply values of 80 and $120 \mathrm{~W}$ cooling is satisfactory for Reynolds numbers higher than 500.

Figure 13 shows the temperature profiles of the electronic heating component versus the Reynolds number when the inlet water temperature was set at $45^{\circ} \mathrm{C}$. For $120 \mathrm{~W}$ power supplies, the temperature difference between the heating component and the critical temperature value of $80^{\circ} \mathrm{C}$ was about $7^{\circ} \mathrm{C}$ for a Reynolds number of $250,17^{\circ} \mathrm{C}$ when the Reynolds number was increased to 500 and between 20 and $25^{\circ} \mathrm{C}$ for higher values of the Reynolds number. It is important that to ensure proper operation of the heating component in this case, the Reynolds number must be above 500. For the other two values of power supply, the temperature difference between the heating component and the 
critical value was higher than $17^{\circ} \mathrm{C}$ for the whole range of the Reynolds number. At a $45^{\circ} \mathrm{C}$ inlet water temperature, cooling of the solar cells was inefficient in all cases considered, except when the power supply was set at $50 \mathrm{~W}$ and the Reynolds number at 2000.

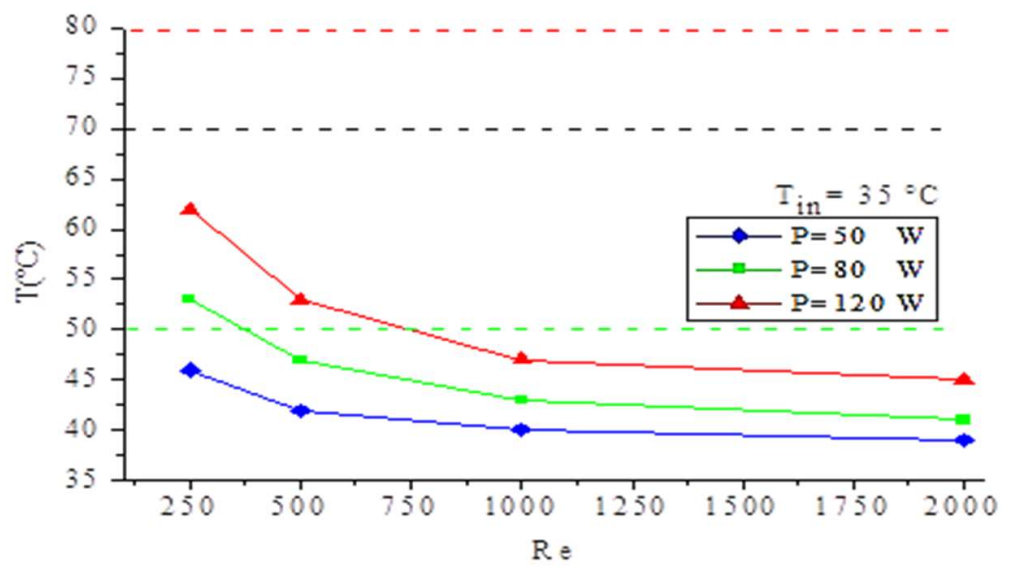

Figure 12. Temperature profiles of the heating component versus the Reynolds number at an inlet water temperature of $35^{\circ} \mathrm{C}$ and power supplies of 50,80 and $120 \mathrm{~W}$.

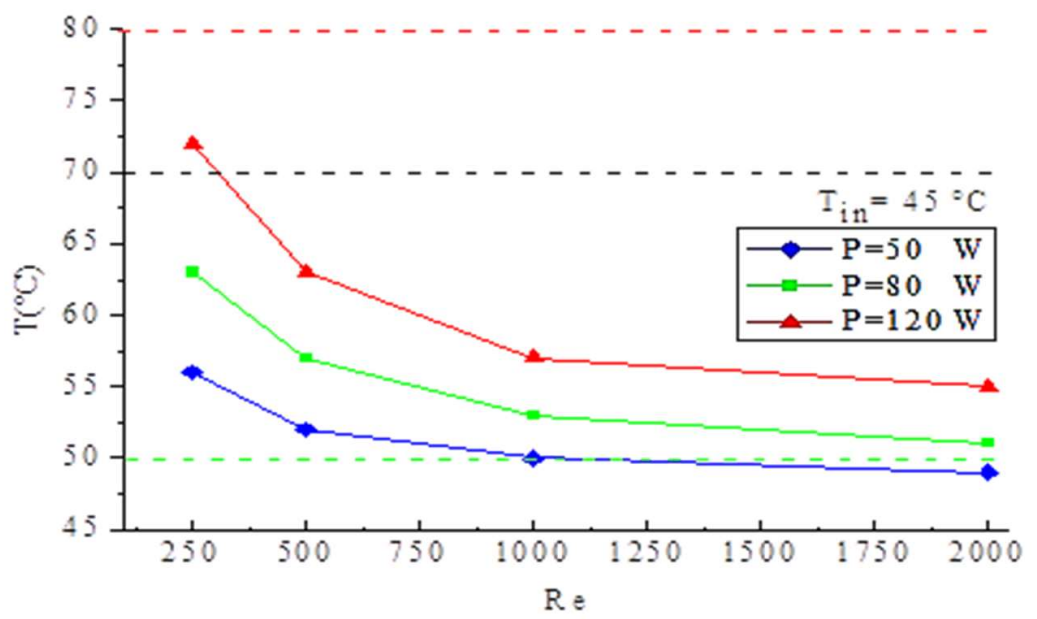

Figure 13. Temperature profiles of the heating component versus Reynolds number at an inlet water temperature of $45^{\circ} \mathrm{C}$ and power supplies of 50,80 and $120 \mathrm{~W}$.

For an inlet water temperature of $55^{\circ} \mathrm{C}$ (Figure 14) and a power supply of $120 \mathrm{~W}$ the temperature of the heating component was higher than the critical temperature value of $80^{\circ} \mathrm{C}$ when the Reynolds number was set at 250 . On increasing the Reynolds number to 500, the temperature difference between the heating component and the critical temperature was about $8^{\circ} \mathrm{C}$. This temperature difference was maintained almost constant at $16^{\circ} \mathrm{C}$ when the Reynolds number was varied between 1000 and 2000. As regards the power supply of $80 \mathrm{~W}$, the corresponding values of the temperature difference between the heating component and the critical temperature value were $7^{\circ} \mathrm{C}$ for $\operatorname{Re}=250,13^{\circ} \mathrm{C}$ for $\mathrm{Re}=500$ and $15^{\circ} \mathrm{C}$ for Reynolds numbers ranging from 1000 to 2000 . For a power supply of $50 \mathrm{~W}$, this temperature difference varied between 14 and $21^{\circ} \mathrm{C}$ for the whole range of Reynolds numbers taken into consideration. 


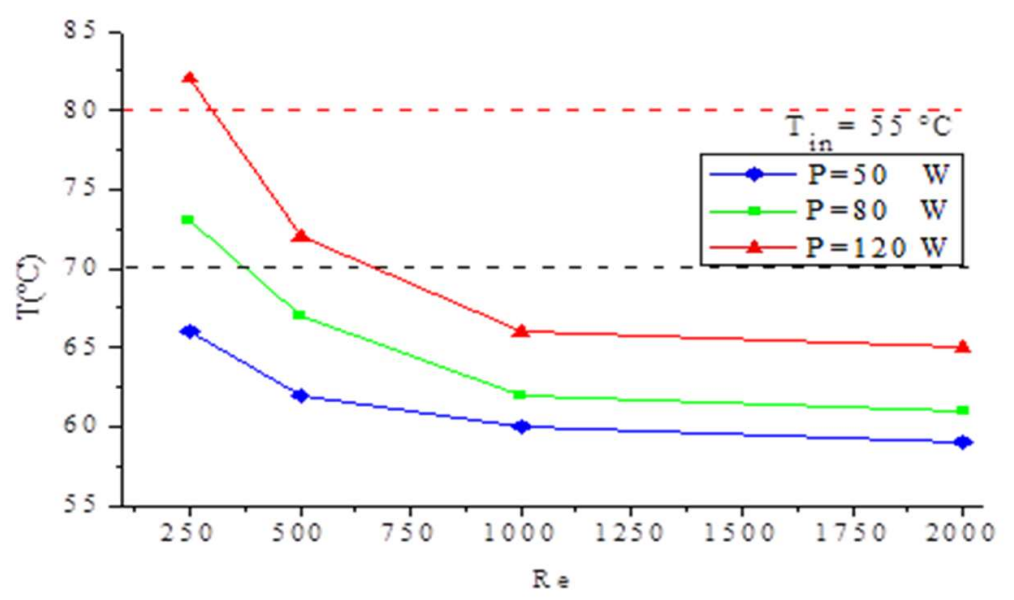

Figure 14. Temperature profiles of the heating component versus Reynolds number at an inlet water temperature of $55^{\circ} \mathrm{C}$ and power supplies of 50,80 and $120 \mathrm{~W}$.

Figure 15 shows that, when the inlet water temperature was set at $65^{\circ} \mathrm{C}$ and the power supply at $120 \mathrm{~W}$ the temperature of the heating component was higher than the critical temperature for Reynolds numbers below 500 . However, the temperature difference between the heating component and the critical value was just about $5^{\circ} \mathrm{C}$ for Reynolds number ranging from 1000 to 2000. This temperature difference was too small and as such presented a risk for the operation of electronic heating components in these working conditions. In the case of a power supply of $80 \mathrm{~W}$, the temperature of the heating component was above the critical temperature $\left(80^{\circ} \mathrm{C}\right)$ for $\mathrm{Re}=250$ and very near to the critical value for Reynolds numbers over 500. Moreover, for a $50 \mathrm{~W}$ power supply, the temperature of the heating component was between 5 and $10^{\circ} \mathrm{C}$ below the critical temperature for the whole range of Reynolds numbers taken into consideration.

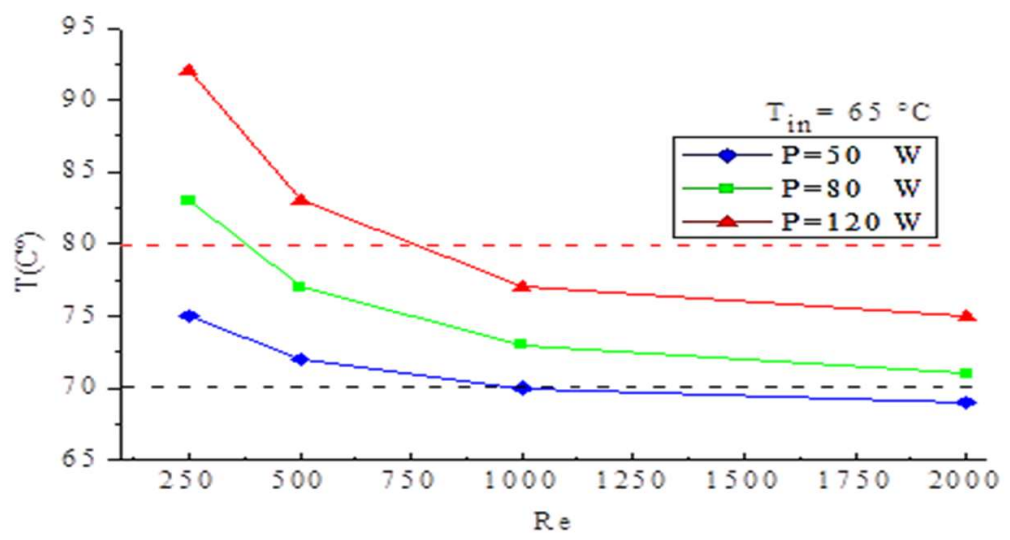

Figure 15. Temperature profiles of the heating component versus Reynolds number at an inlet water temperature of $65^{\circ} \mathrm{C}$ and power supplies of 50,80 and $120 \mathrm{~W}$.

Figure 16 shows the variation of heat dissipation efficiency as a function of the Reynolds number for the power supplies considered for the electronic heating component in the present work, i.e. 50,80 and $120 \mathrm{~W}$, at a $45^{\circ} \mathrm{C}$ inlet water temperature.

Figure 17 shows the contours of the axial velocity of the flow for different values of the Reynolds number in the micro-channels, namely 250,500, 1000 and 2000. This velocity varied from a minimum at the inlet of the microchannels to a maximum value at the outlet. The presence of a recirculation zone in the two collector tubes just at the outlet of the micro-channel is worthy of note. When the Reynolds number was increased, the area of the recirculation zone in the entrance collector increased and created a disturbance in the flow at the entrance of the micro-channels. 


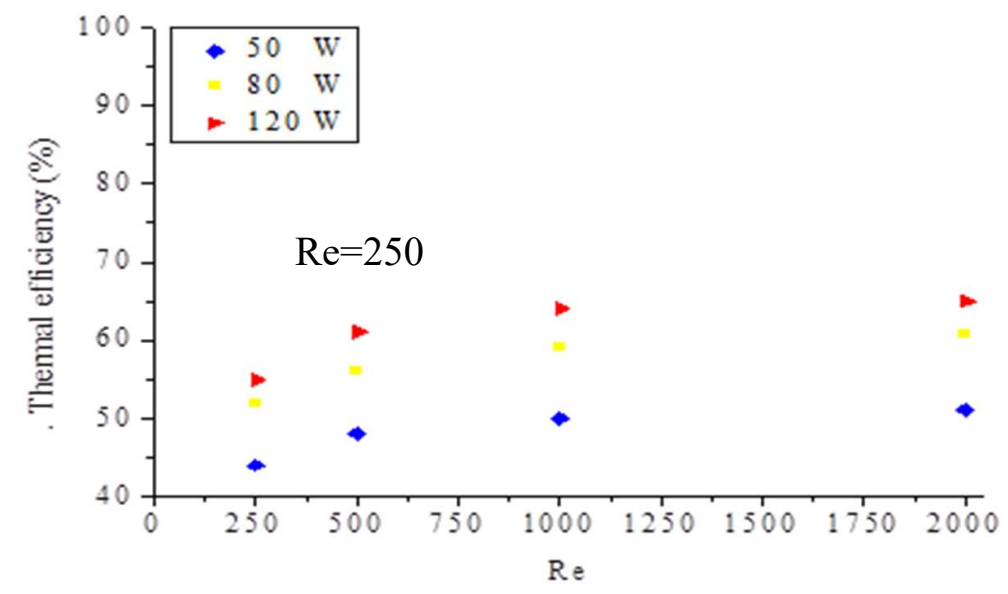

Figure 16. Thermal efficiency of the micro heat exchanger circulating hot water versus Reynolds number for power supplies of 50,80 and $120 \mathrm{~W}$.
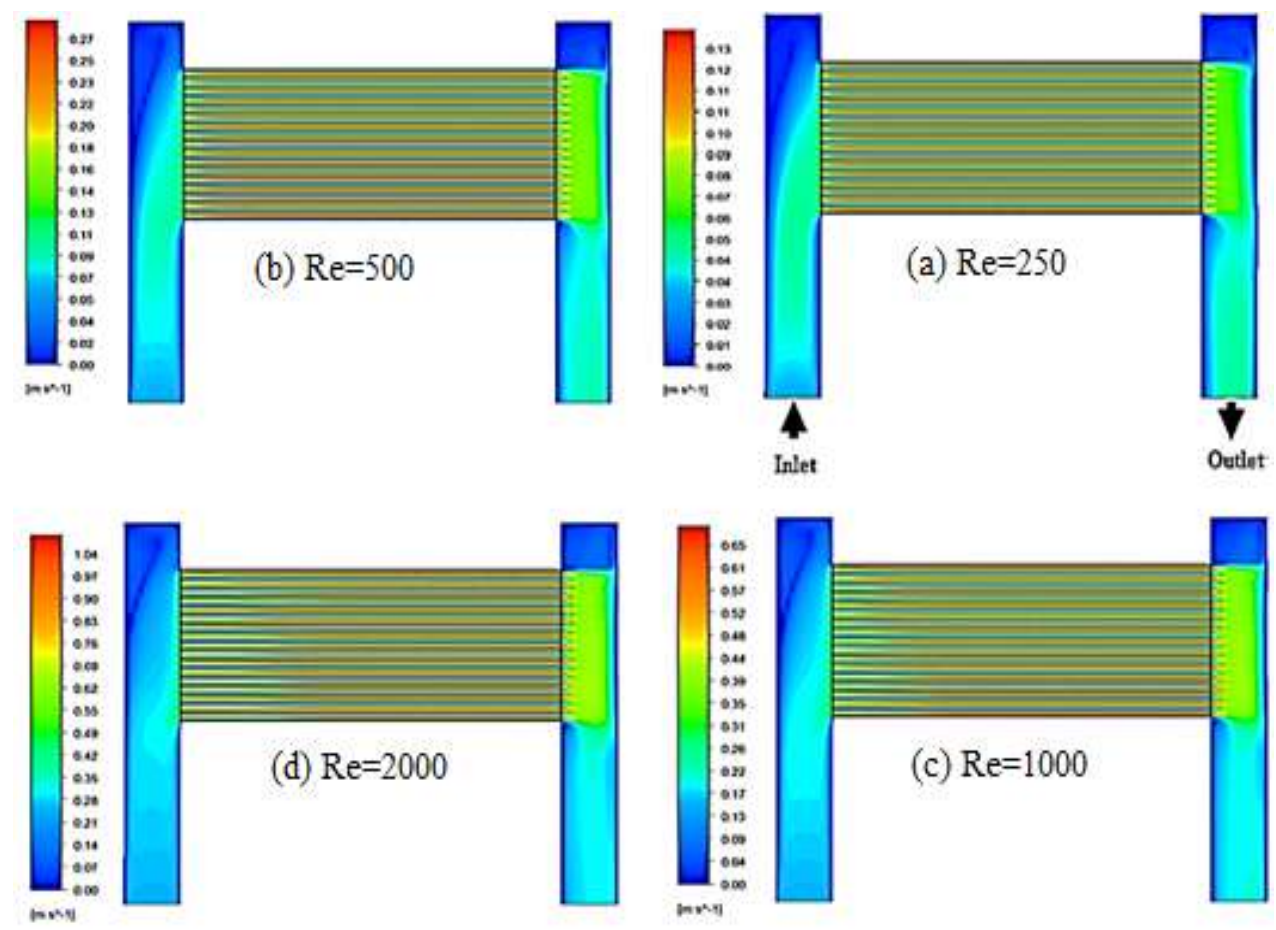

Figure 17. Contours of the axial velocity on the horizontal plane of the micro heat exchanger for Reynolds numbers of 250, 500, 1000 and 2000.

Figure 18 shows the velocity profiles in two traversal locations $y=(0,0.022)$ in the micro-channels. The velocity was zero near the wall and increased to a maximum at the center of the micro-channels, thus fulfilling mass conservation. The velocity increased progressively from the wall to the center of the micro-channels and reached maximum values $\left(\mathrm{v}_{\max }\right)$ of $0.14,0.28,0.68$ and $1.1 \mathrm{~m} / \mathrm{s}$ at the outlet of the micro-channels for Reynolds numbers of 250, 500, 100 and 2000, respectively. The flow was fully developed at $5 \mathrm{~mm}$ from the entrance for the Reynolds numbers of 250 and 500 , after $10 \mathrm{~mm}$ for $\mathrm{Re}=1000$ and at $15 \mathrm{~mm}$ from the entrance for the Reynolds number of 2000 . The velocity profile was almost uniform on reaching a fully developed flow in the 17 micro-channels with the application of the Reynolds numbers considered. It is important to remember that the micro-channel length was 40 $\mathrm{mm}$. 
(b) $\mathrm{Re}=500$

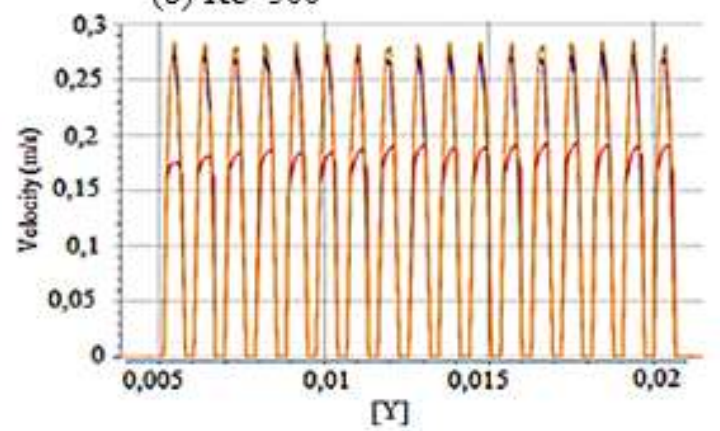

(d) $\operatorname{Re}=2000$

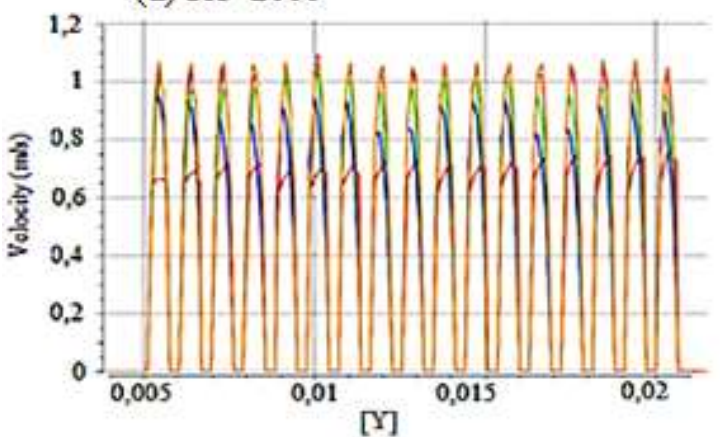

(a) $\operatorname{Re}=250$

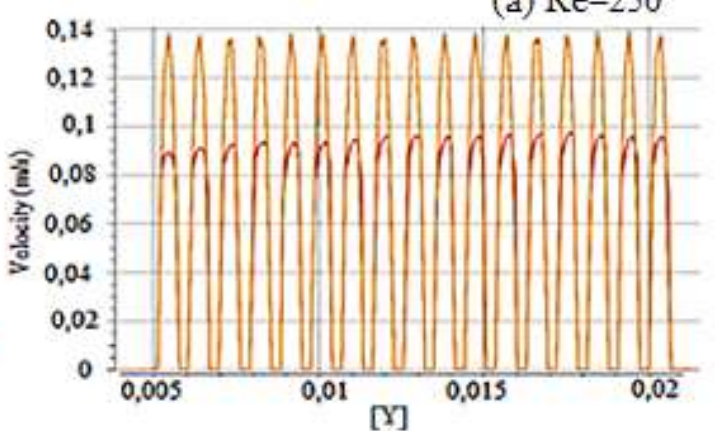

(c) $\operatorname{Re}=1000$

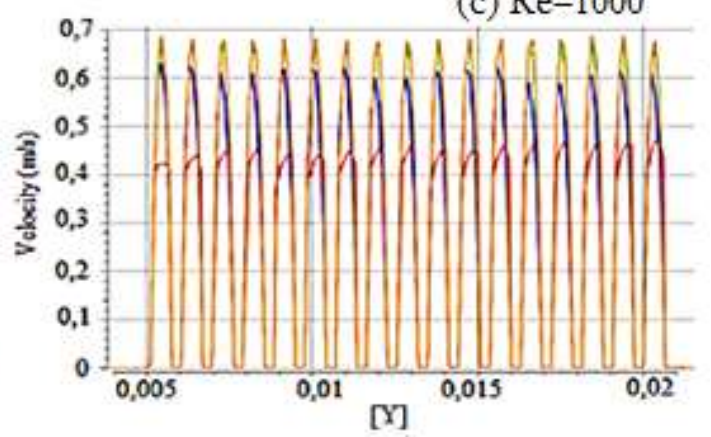

Figure 18. Velocity profile as a function of the location in the micro-channels for Reynolds numbers of 250, 500, 1000 and 2000.

\section{CONCLUSIONS}

The main objective of the present paper is to assess the thermal performance of a hot water micro heat exchanger used for cooling electronic heating components or solar cells. The effect of the inlet temperature and flow configuration of water flowing in the micro-channels was investigated. A micro heat exchanger was designed and experimentally tested in cooling mode, using distilled water. The results obtained were compared with those obtained from a CFD numerical simulation. The water inlet temperature ranged from 25 to $65^{\circ} \mathrm{C}$ at $10^{\circ} \mathrm{C}$ intervals and the Reynolds number from 250 to 2000 . Power supplies of 50, 80 and $120 \mathrm{~W}$ for the electronic heating components were also considered. The maximum operating temperature permitted was $80^{\circ} \mathrm{C}$ for the electronic components and $50^{\circ} \mathrm{C}$ for solar cells. The most significant results are herein summarized.

- Both experimental and numerical results show that it was possible to cool electronic heating components with water inlet temperatures of up to $55^{\circ} \mathrm{C}$ and Reynolds members ranging from 250 to 2000 for power supply values of 50 and $80 \mathrm{~W}$. However, for a $120 \mathrm{~W}$ power supply, effective cooling was only possible for Reynolds numbers above 750 .

- The cooling of solar cells was feasible with inlet water temperatures below $35^{\circ} \mathrm{C}$ and at higher temperatures, cooling was inefficient.

- At an inlet water temperature of $45^{\circ} \mathrm{C}$, the micro heat exchanger was able to dissipate about $45-65 \%$ of the heat released by electronic heating components. At a higher inlet temperature, there was a risk of the electronic components, overheating i.e., working temperatures above the critical value of $80^{\circ} \mathrm{C}$, with a Reynolds number of 250 for power supplies higher than $80 \mathrm{~W}$.

- Cooling of the electronic components at an inlet water temperature of $65^{\circ} \mathrm{C}$ was not feasible for the whole range of the Reynolds number and power supplies, i.e., the 50,80 and $120 \mathrm{~W}$, considered in the present work. 
- Flow hydrodynamic in the micro-channels was also investigated in terms of uniformity and flow configuration. The numerical results show that the flow velocity was uniform in micro-channels. A uniform distribution of the coolant stream is of great importance for the operation of electronic components as it means a uniform temperature distribution and a homogenous cooling.

As future work, it is important to complete this study by the investigation of the heat transfer intensification synergy and integration of nanoparticles in electronic cooling systems.

\section{ACKNOWLEDGEMENTS}

Mahdi Mokrane gratefully acknowledges the Development Unit of Solar Equipments (UDES) of the EPST/Renewable Energy Development Center (CDER) of Algeria for funding his internships at RoviraiVirgili University of Tarragona (Spain).

\section{NOMENCLATURE}

$\begin{array}{ll}\mathrm{C}_{\mathrm{p}} & \text { Specific heat }(\mathrm{J} / \mathrm{kg} . \mathrm{K}) \\ \mathrm{D}_{\mathrm{c}} & \text { Collector diameter }(\mathrm{mm}) \\ \mathrm{D}_{\mathrm{h}} & \text { Hydraulic diameter }(\mathrm{mm}) \\ \mathrm{e} & \text { Thickness of pin fin }(\mathrm{mm}) \\ \mathrm{e}_{\mathrm{s}} & \text { Thickness of the upper face of heat sink }(\mathrm{mm}) \\ \mathrm{H} & \text { Heat sink height }(\mathrm{mm}) \\ \mathrm{k} & \text { Thermal conductivity }(\mathrm{W} / \mathrm{m} . \mathrm{K}) \\ \mathrm{I} & \text { Electrical intensity }(\mathrm{A}) \\ \mathrm{L}_{\mathrm{c}} & \text { Collector distance after the heat sink }(\mathrm{mm}) \\ \mathrm{L} & \text { Heat sink length }(\mathrm{mm}) \\ \mathrm{N} & \text { Number of channels }(-) \\ \mathrm{P} & \text { Electric power }(\mathrm{W}) \\ \mathrm{Q} & \text { Heat transfer rate }(\mathrm{W}) \\ \mathrm{Re} & \text { Reynolds Number, }(-) \\ \mathrm{t} & \text { Time }(\mathrm{s}) \\ \mathrm{T} & \text { Temperature }\left({ }^{\circ} \mathrm{C}\right) \\ \mathrm{u}, \mathrm{v}, \mathrm{w} & \text { Velocity in the directions x, y and } \mathrm{z}(\mathrm{m} / \mathrm{s}) \\ \mathrm{U} & \text { Voltage }(\mathrm{V}) \\ \mathrm{W} & \text { Heat sink width }(\mathrm{mm}) \\ & \end{array}$




\section{REFERENCES}

[1] Yang Q, J. Zhao Y, Huang X, Zhu W, Fu C, Li J, Miao. A diamond made microchannel heat sink for highdensity heat flux dissipation. Applied Thermal Engineering, 158,113804, 2019. https://doi.org/10.1016 /j. applthermaleng.2019.113804.

[2] Zou Y, Wang Y, Xu S, Jin T, Wei D, Ouyang J, Jia D, Zhou Y. Superhydrophobic double-layer coating for efficient heat dissipation and corrosion protection. Chemical Engineering Journal, 362, pp.638-649, 2019. https://doi.org/10.1016/j.cej.2019.01.086

[3] Lower N.P, Boone A.P, Wilcoxon R.K, Hillman D.D. Alkali silicate glass-based coating and method for applying. US 8,617,913 B2. Dec. 31, 2013.

[4] Oruji S, Brake N.A, Guduru R.K, Nalluri L, Günaydın-Sen Ö, Kharel K, Rabbanifar S, Hosseini S, Ingram E. Mitigation of ASR expansion in concrete using ultra-fine coal bottom ash. Construction and Building Materials, 202, pp. 814-824, 2019. https://doi.org/10.1016/j.conbuildmat.2019.01.013

[5] Prajapati Y.K. Influence of fin height on heat transfer and fluid flow characteristics of rectangular microchannel heat sink. International Journal of Heat and Mass Transfer, 137, pp. 1041-1052, 2019. https://doi.org/10.1016 /j. ijheatmasstransfer.2019.04.012.

[6] Tuckerman D.B, Pease R.F.W. High-performance heat sinking for VLSI. IEEE Electron Device Letters, Vol. EDL-2, No. 5, pp. 126-129, May 1981. doi: 10.1109/EDL.1981.25367

[7] Goldberg N. Narrow channel forced air heat sink. IEEE Transaction on Components, Hybrid, and Manufacturing Technology, GHMT-7, pp. 154- 159, 1984. doi: 10.1109/TCHMT.1984.1136326

[8] Mahalingam M. Thermal management in semiconductor device packing. IEEE Proc. 73, pp. 1396-1404, 1985. doi: 10.1109/PROC.1985.13300

[9] Mehendafe S.S, Jacobi A.M, Shah R.K. Fluid flow and heat transfer at micro- and meso scales with application to heat exchanger design. Applied Mechanics Reviews, 53 (7), pp. 175-193, 2000. https://doi.org /10.1115/1 .3097347

[10] Kandlikar S.G, Grande W.J. Evolution of microchannel flow passages: thermohydraulic performance and fabrication technology. Heat Transfer Engineering, 24(1), 3-17.2003. doi:10.1080/01457630304040.

[11] Cavallini A, Censi G, Del Col D, Doretti L, Longo A.G, Rossetto L. Condensation heat transfer and pressure drop inside channels for $\mathrm{AC} / \mathrm{HP}$ application. In Proceedings of the 12th International Heat Transfer Conference, 1, pp. 171-186, 2002. doi: 10.1615/IHTC12.3230.

[12] Noh N.M, Fazeli A, Nor Azwadi C.S. Numerical simulation of nanofluids for cooling efficiency in microchannel heat sink. Journal of Advanced Research in Fluid Mechanics and Thermal Science, 4, pp. 13-23, 2014. https://doi.org/10.1080/00319104.2017.1336237.

[13] Abubakar S. B, Nor Azwadi C.S. Numerical prediction of laminar nanofluid flow in rectangular microchannel heat sink. Journal of Advanced Research in Fluid Mechanics and Thermal Science, 7, pp. 29-38, 2015.

[14] Abubakar S, Nor Azwadi C.S, Ahmad A. The use of $\mathrm{Fe}_{3} \mathrm{O}_{4}-\mathrm{H}_{2} \mathrm{O}_{4}$. Nanofluid for heat transfer enhancement in rectangular microchannel heat sink. Journal of Advanced Research Materials Science, 23, pp. 15-24, 2016.

[15] Peng X.F, Peterson G.P. The effect of thermofluid and geometrical parameters on convection of liquids through rectangular microchannels. International Journal of heat and mass transfer, 38(4), pp. 755-758, 1995. https://doi.org/10.1016/0017-9310(95)93010-F.

[16] Gao P, Le Person S, Favre-Marinet M. Scale effects on hydrodynamics and heat transfer in two-dimensional mini and microchannels. International Journal of Thermal Sciences, 41(11), pp. 1017-1027, 2002. https://doi .org/10.1016/S1290-0729(02)01389-3

[17] Philips R.J. Forced-convection, liquid-cooled microchannel heat sinks. PhD thesis, MIT, 1988.

[18] Qu W, Mudawar I. Experimental and numerical study of pressure drop and heat transfer in a single-phase microchannel heat sink. International Journal of Heat and Mass Transfer, 45, pp. 2549-2565, 2002. https://doi. org/10.1016/S0017-9310(01)00337-4 
[19] Philip Ball, Computer engineering: Feeling the heat, Nature 492,174-176, (13 December 2012). doi: $10.1038 / 49$ 2174a

[20] Zimmermann S, Tiwari M. K, Meijer I, Paredes S, Michel B, Poulikakos D. Hot water cooled electronics: Exergy analysis and waste heat reuse feasibility. International Journal of Heat and Mass Transfer, 55 (23-24), pp. 6391-6399, 2012. https://doi.org/10.1016/j.ijheatmasstransfer.2012.06.027.

[21] Philips R.J. Forced-convection, liquid-cooled microchannel heat sinks. Master Thesis, Massachusetts Institute of Technology, Cambridge, MA, 1987.

[22] Kawano K, Minakami K, Iwasaki H, Ishizuka M. Micro channel heat exchanger for cooling electrical equipment. Application of Heat Transfer in Equipment, Systems and Education. ASME HTD-361-3/PID-3, pp. 173-180, 1998.

[23] Wu H.Y, Cheng P. An experimental study of convective heat transfer in silicon microchannels with different surface conditions. International journal of Heat and Mass Transfer.46 (14), pp. 2547-2556, 2003. https://doi .org/10.1016/S0017-9310(03)00035-8

[24] McHale J.P, Garimella S.V. Heat transfer in trapezoidal microchannels of various aspect ratios. International journal of Heat and Mass Transfer. 53 (1-3), pp.365-375, 2010. https://doi.org/10.1016/j.ijheatmasstransfer. 2009.09.020

[25] Yang Y.T, Liao S.C. Numerical optimization of trapezoidal microchannel heat sinks. International journal of mechanical, aerospace, industrial and mechatronics engineering. 8 (8) pp. 1374-1377, 2014. doi.org/10.5281 /zenodo.1094233

[26] Tiselj I, Hetsroni G, Mavko B, Mosyak A, Pogrebnyak E, Segal Z. Effect of axial conduction on the heat transfer in micro-channels. International journal of Heat and Mass Transfer, 47 (12-13), pp. 2551-2565, 2004. https://doi.org/10.1016/j.ijheatmasstransfer.2004.01.008.

[27] Celata G.P, Cumo M, Marconi V, Mc Phail S.J, Zummo G. Microtube liquid single-phase heat transfer in laminar flow. International Journal of Heat and Mass Transfer, 49 (19-20), pp. 3538-3546, 2006. https://doi. org/10.1016/j.ijheatmasstransfer.2006.03.004

[28] Nonino C, Savino S, Del Giudice S, Mansutti L. Conjugate forced convection and heat conduction in circular microchannels. International Journal of Heat Fluid Flow, 30 (5), pp. 823-830, 2009. https://doi.org/10.1016/j. ijheatfluidflow.2009.03.009

[29] Zhang S.X, He Y.L, Lauriat G, Tao W. Numerical studies of simultaneously developing laminar flow and heat transfer in micro tubes with thick wall and constant outside wall temperature. International journal of Heat and Mass Transfer, 53 (19-20), pp. 3977-3989, 2010. https://doi.org/10.1016/j.ijheatmasstransfer.2010.05.017.

[30] Pan M, Wang H, Zhong Y, Hu M, Zhou X, Dong G, Huang P. Experimental investigation of the heat transfer performance of microchannel heat exchangers with fan-shaped cavities. International Journal of Heat and Mass Transfer, 134, pp. 1199-1208, 2019. https://doi.org/10.1016/j.ijheatmasstransfer.2019.01.140.

[31] Abdul Hasis F. B, Mithun Krishna P.M, Aravind G. P, Deepu M, Shine S.R. Thermo hydraulic performance analysis of twisted sinusoidal wavy microchannels. International Journal of Thermal Sciences, 128, pp. 124136, 2018. https://doi.org/10.1016/j.ijthermalsci.2018.02.018.

[32] Sui Y, Lee P.S, Teo C.J. An experimental study of flow friction and heat transfer in wavy microchannels with rectangular cross section. International Journal of Thermal Science.50, pp. 2473-2482, 2011. https://doi.org/10 .1016/j.ijthermalsci.2011.06.017

[33] Vafaie R.H, Mahdipour M, Mirzajani H, Ghavifekr H.B. Numerical simulation of mixing process in tortuous microchannel. Sensors and Transducers, 151 (4), pp. 30-35, 2013.

[34] Dai Z, Fletcher D.F, Haynes B.S. Impact of tortuous geometry on laminar flow heat transfer in microchannels. International Journal of Heat and Mass Transfer, 83, pp. 382-398, 2015. https://doi.org/10.1016/j.ijheat mass transfer.2014.12.019

[35] Hao X, Peng B, Xie G, Chen Y. Thermal analysis and experimental validation of laminar heat transfer and pressure drop-in serpentine channel heat sinks for electronic cooling. Journal of Electronic Packaging, Transactions of the ASME, 136 (3), Article number 031009, 2014. https://doi.org/10.1115/1.4027508.

[36] Pantakar S.V. Numerical Heat Transfer and Fluid Flow. Hemisphere Publishing Corporation, 1980. 